Journal of Agricultural Sciences
(Tarim Bilimleri Dergisi)

\title{
Characterization of Antimicrobial Peptide Fraction Producing Lactobacillus spp. Based on LC/MS-MS and Determination of ACE-inhibitory Activity in Kefir
}

\author{
Merve ATALAY ${ }^{\mathrm{a}}(\mathbb{D})$, Didem ŞAHINGIL ${ }^{\mathrm{a}^{*}}$ (i) \\ ${ }^{a}$ Department of Food Engineering, Engineering Faculty, Inonu University, 44280 Malatya, TURKEY \\ ARTICLE INFO \\ Research Article \\ Corresponding Author: Didem ŞAHINGiL, E-mail: didem.sahingil@inonu.edu.tr \\ Received: 15 February 2021 / Revised: 08 June 2021 / Accepted: 09 June 2021 / Online: 01 September 2022 \\ Cite this article \\ Atalay M, SAHINGIL D (2022). Characterization of Antimicrobial Peptide fraction producing Lactobacillus spp. based on LC/MS-MS and Determination of ACE-inhibitory activity \\ in Kefir. Journal of Agricultural Sciences (Tarim Bilimleri Dergisi), 28(3):372-384. DOI: 10.15832/ankutbd.880744
}

\section{ABSTRACT}

In the present study, bioactive properties such as ACE-I activity and antimicrobial activity of kefir using different Lactobacillus (Lactobacillus delbrueckii ssp. bulgaricus ATCC 11842, Lactobacillus helveticus ATCC 15009 and Lactobacillus plantarum ATCC 14917) on some pathogen and Gram-positive bacteria during 28 day-storage periods was investigated and proteolysis (RP-HPLC peptide profiles, RP-HPLC amino acid profiles) were studied. The antimicrobial activity was investigated in kefir extract and separated peptide fractions $(<3 \mathrm{kDa}$, named F2) which were characterized by LC-MS/MS and precursor and product ions were determined. Antimicrobial activity has been observed against pathogenic bacteria such as Escherichia coli (E. coli) in all samples. But the results revealed that the F2 fraction separated from kefir manufactured using Lactobacillus had a stronger antibacterial effect than control samples. It was determined that the F2 fraction has antimicrobial activity against $S$. aureus, $S$. warneri 95052 and $S$. hominis. The ACE-I activity of samples A, B, C and K were $76.47 \%, 84.95 \%, 87.33 \%$ and $85.57 \%$, respectively. In the kefir using Lactobacillus has increase of ACE-I activity and was significant $(\mathrm{P}<0.01)$. In this study, it was concluded that the using of adjunct Lactobacillus contributed to the functional value of kefir.

Keywords: Bioactive peptides, In-Vitro antimicrobial peptides, ACE- I activity, purification, LC-MS/MS

\section{Introduction}

Kefir is a fermented dairy beverage produced by the actions of the microflora encased in the "kefir grain", the composition differing according to the source, are a symbiotic association of a variety of bacteria and fungi, such as lactic acid bacteria, acetic acid bacteria, yeasts and molds, etc., originated thousands of years ago in the Caucasus (Pogačić et al. 2013; Purutoglu et al. 2020; Wang et al. 2021). In kefir, the predominant genus was Lactobacillus. Low abundant genera, such as Leuconostoc, Lactococcus, Streptococcus, Acetobacter, etc were also found from different grains. Yeasts were abundant in fungal microbiota of kefir grains and genera belonging to Saccharomyces, Kazachstania, Kluyveromyces, Pichia, etc. (Tas et al. 2012; Prado et al. 2015; Garofalo et al. 2015). The microbiota of kefir grains has been found depending several factors such as the origin of the kefir grain, grain cultivation methods, sanitation conditions, production and storage conditions (Witthuhn et al. 2004; Gul et al. 2018). Accordingly, the differences of microbiota in kefir grains can be responsible for important changes in nutritional and flavor properties of kefir product. It has been determined that milk proteins have the physiological activities by some peptides that are digested with gastric and pancreatic enzymes (Schanbacher et al. 1998). Peptides resulting from proteolysis by microorganisms in kefir grains partially responsible for the biological activity of kefir. Bioactive peptides have been proposed as health-promoting compounds and these peptides comprising 2 to 20 amino acids residues with functional and biological properties such as antihypertensive, antioxidant, antimicrobial, anticancer and opioid (Karami \& Akbari-Adergani 2019; Zhu et al. 2019). Many of studies have investigated production and activity of bioactive peptides, i.e. antioxidants, antimicrobial, antithrombotic and immunomodulatory activities (Chandra \& Viji 2018; Chandra et al. 2019). Among these peptides, one of the most important and widely studied is ACE-I peptides. ACE is an exopeptidase and it elicits dipeptides from the C-terminal ends of various peptide substrates (Pihlanto-Leppälä 2000). Bioactive compound production may be strikingly increased by controlling the fermentation conditions (Zajsek \& Gorsek 2011). Either as starter, as adjunct cultures, or as probiotics, lactobacillus strains are used as food preservatives not only to prevent the development of food spoilage but also to give consumers a health benefit. Some lactobacilli produce bacteriocins, proteins active against other bacteria. According to the literature is examined, it has been found that lactic acid bacteria such as L. helveticus, L. casei are extensively used in the fermentation of some dairy products (Nielsen et al. 2009; Otte et al. 2011; Sanl1 et al. 2018). In a study, it was reported that the antihypertensive peptides can be produced during fermentation of lactic acid bacteria used as adjunct cultures in kefir production contributed in different ways to peptides and also slightly contributed to the formation of ACE-I peptides (Sanl1 et al. 2018). However, only a few studies have been published on the ACE-I activity of kefir (Maeda et al. 2004; Quiros et al. 2005) and it needs to be further studied. The types and strains of starter microorganisms used in kefir have affected the bioactivity of the product. The data obtained in a 
study showed that the variability in the amino acid content of kefir is a function of the culture type (Ozcan et al. 2019). It was determined that the principal amino acids of buffalo milk kefir produced either by grains or adjunct starter culture were glutamic acid, alanine, serine, tyrosine and the like (Ozcan et al. 2019). Bioactive peptides originating from milk proteins were identified in amino acid sequences of these proteins. It has been shown that these peptides can be expressed by bacterial microbial, coagulant, digestive enzymes, and exogenously added starter lactic acid bacteria (Gobbetti et al. 2002). For this reason, functional foods and bioactive components have begun to attract the attention of food scientists, nutritionists, health professionals and consumers. In a study, it was reported that kefir enriched in terms of probiotic microorganisms was equivalent to traditionally produced kefir, its bioavailability and functionality has been increased, and it was suitable for industrial production and likeable regarding organoleptic properties. (Karacalı et al. 2018). Furthermore, kefir represents a good choice as a probiotic food carrier, showing potential advantages for human health over other dairy fermented products. Foodborne diseases, which can cause more than 900 million infectious events, have become a public health problem (He et al. 2018). These diseases are caused by eating foods contaminated with pathogenic microorganisms such as $S$. aureus and E. coli. Although the growth of pathogenic bacteria in foods can be effectively controlled with chemical preservatives, consumers are still concerned about some safety issues (Ma et al. 2020). In addition, increased bacterial resistance to common and artificial antibiotics and their side effects have also caused problems in public health leading to the discovery of natural antimicrobial counterparts (Pina-Perez et al. 2015; Sundin \& Wang 2018). In addition to its antibacterial, antifungal and antitumor activities, kefir is effective in improving health, strengthening the immune system, balancing blood pressure and lowering serum cholesterol levels. (Ajam \& Koohsari 2020). Therefore, there is a need for the development of natural antibacterial agents. Recently, antimicrobial peptides (AMPs) have been gaining widespread attention due to their excellent functional activities. Many natural AMPs such as nisin have been reported today (Miao et al. 2016). However, nisin is the only antimicrobial peptide used in the food field as a natural food preservative (Upendra et al. 2016). Therefore, AMPs are of great importance as a potential food preservative. Several studies are investigating the antibacterial activity of kefir. However, little information is readily available concerning the characterization of antimicrobial peptides from kefir produced using Lactobacillus.

This study aimed to the effect of ACE-I activity and the antibacterial activity against selected bacteria in kefir samples produced using Lactobacillus. Also, the results can provide information on the amino acid content, to enable a better understanding of the ACE-I activity of kefir. Additionally, characterization of AMP peptide fractions by Liquid chromatography-Mass spectrometry-Mass spectrometry (LCMS/MS) was provided.

\section{Material and Methods}

\subsection{Materials}

Kefir grains were purchased from a local market and groved in skim milk at $22{ }^{\circ} \mathrm{C}$ for 24 hours a day. The kefir granules were obtained by continuously growing in skimmed milk. Kefir grains, raw cow's milk used in the production of kefir samples and Lactobacillus delbrueckii ssp. bulgaricus (L. delbrueckii ssp. bulgaricus) ATCC 11842, Lactobacillus helveticus (L. helveticus) ATCC 15009, Lactobacillus plantarum (L. plantarum) ATCC 14917 used adjunct cultures were provided from the Food Engineering of Inonu University Engineering Faculty (Malatya, Turkey). Raw cow's milk was heated $55-60{ }^{\circ} \mathrm{C}$, then fat value was standardized to $2 \%$ with a cream separator. After pasteurization $\left(90^{\circ} \mathrm{C}\right.$ for $\left.5 \mathrm{~min}\right)$, the milk was cold at inoculation temperature $\left(23^{\circ} \mathrm{C}\right)$ and is divided into 2 parts. The first part of milk at aseptic conditions, $3 \%$ kefir grains are inoculated and incubation is continued for approximately $22-24$ hours at $20-25^{\circ} \mathrm{C}$. When the curd acidity reaches $\mathrm{pH} 4.6$, the incubation process was terminated and the kefir grains were separated by filtration (sample $\mathrm{K}$ ). Second part of milk was inoculated kefir grains at level of $3 \%$ (w/v) and the incubation was continued for approximately $22-24$ hours at $20-25^{\circ} \mathrm{C}$ until pH 4.8, the kefir grains were separated by filtration. The fermented milk divided into 3 parts. Each part was inoculated with the adjunct starter culture (sample A: L. delbrueckii ssp. bulgaricus, sample B: L. helceticus, sample C: L. plantarum, $1 \mathrm{~mL}$ per $100 \mathrm{~mL}$ ). When the second incubation reaches $\mathrm{pH} 4.6$ at $37^{\circ} \mathrm{C}$, the incubation process was terminated. Kefir samples are stored in $200 \mathrm{~mL}$ plastic containers at $4{ }^{\circ} \mathrm{C}$ during 28 days.

A $20 \mathrm{~g}$ of Kefir sample was mixed $10 \mathrm{~mL}$ deionized water and incubated in a shaking water bath for 1 hour at $40 \pm 1{ }^{\circ} \mathrm{C}$. Kefir was centrifuged at $3000 \times \mathrm{g}$ for $30 \mathrm{~min}$ at $4^{\circ} \mathrm{C}$ with a cooled centrifuge (model 320R, Hettich, Tutlingen, Germany). Supernatants were filtered through qualitative filter paper (Whatman No: 113) The water-soluble nitrogen (WSN) fractions were freeze-dried used to HPLC peptides analysis and ACE-I activity analysis and antimicrobial activity of the kefir samples.

\subsection{Proteolysis}

Peptide profile of the freeze-dried WSN fractions of the kefirs was analyzed by reverse-phase high performance liquid chromatography (RP-HPLC) (Shimadzu LC 20 AD Prominence HPLC) system (Shimadzu Corporation, Kyoto, Japan) according to the method described by Sulejmani \& Hayaloglu (2017). The RP-HPLC individual free amino acids contents of water-soluble fractions were determined as previously described by Hayaloglu (2007). The total Free Amino Acids (FAAs) content of the kefir samples was determined by the method described in Sahingil et al. (2019).

\subsection{RP-HPLC determination of angiotensin-converting enzyme activity}

The ACE-I activity and $\mathrm{IC}_{50}$ value were determined as previously described by Sahingil et al. (2019). 
$I C_{50}=\frac{B S A x 50}{I R}$

BSA (Bovine Serum Albumine): mg/L; IR: ACE inhibition rate (\%)

\subsection{Antimicrobial activity}

The antimicrobial activity assay was studied in both kefir and WSN fractions obtained from kefir. The kefir was centrifuged at $3000 \times g$ for $30 \mathrm{~min}$ and the supernatant passed through $0.45 \mu \mathrm{m}$ pore size filter for sterilized. The supernatans were kept at refrigerator temperature until antibacterial activity tests. WSN fractions were freze-dried used for antimicrobial activity tests. The dried water-soluble fractions were dissolved in ultrapure water to $50 \mathrm{mg} / \mathrm{mL}$. The fractions were separated according to their molecular size using centrifugal filters (Amicon Ultracel-3K, Merck-Millipore Ltd, Cork, Ireland). Then the supernatant was sterilized by filtration using a 0.45 - $\mu \mathrm{m}$ pore size syringe filter. Staphylococcus epidermidis RSKK 0802 (S. epidermidis), Staphylococcus aureus 1021/06008 (S. aureus), Staphylococcus warneri 95052 (S.warneri), Staphylococcus xylosus (S. xylosus), Shigella flexneri RSKK 184 (S. flexneri), Bacillus cereus RS 863 (B. cereus), Escherichia coli (E. coli) (Microbiology laboratory of Inonu University Turgut Özal Medical Center), Enterococcus faecalis (E. fecalis), Candida albicans ATCC 04055 (C.albicans), Streptococcus mutans (Str.mutans), Enterobacter, Salmonella enteritidis (S.enteritidis), Pseudomonas putida (P. putida) were investigated on antimicrobial effect on 13 different microorganisms. They were procured from Inonu University. Then, the bacteria were recovered in the Brain Heart Infusion medium (Merck) at $37^{\circ} \mathrm{C} / 24 \mathrm{hr}$ in the microbiology laboratory of the Inonu University. Antimicrobial inhibition effects on some pathogenic bacteria and yeast were determined by disc diffusion method (0.6 mm disc diameter). The macrodilution tube method was used based on turbidimetric assay and the highest inhibition zone diameter was selected for the minimum inhibitory concentration (MIC) of kefir. For WSN fractions 5 different concentrations (50-200 mg/mL; 50-75-100-150$200 \mathrm{mg} / \mathrm{mL}$ ) which prepared in Nutrient Broth (Merck) were studied for determination of minimum inhibitory concentration. The dilution $(100 \mathrm{mg} / \mathrm{mL})$ in which microbial turbidity was not observed, as the MIC was reported. A hundred microliters of each WSN extract were by disk diffusion method onto the surface of the agar. For kefir extract 10 different concentrations (100-1000 $\mu \mathrm{L} / \mathrm{mL} ; 100-200-300-400$ 500-600-700-800-900-1000 $\mu \mathrm{L} / \mathrm{mL})$ were studied for determination of minimum inhibitory concentration. The dilution $(1000 \mu \mathrm{L} / \mathrm{mL})$ in which microbial turbidity was not observed, as the MIC was reported. The plates were incubated for $24 \mathrm{~h}$ at $37^{\circ} \mathrm{C}$ in anaerobic media. The lyophilized peptide fractions $(100 \mathrm{mg} / \mathrm{mL})$ were dissolved in $40 \mathrm{mM}$ sodium phosphate buffer $(\mathrm{pH} 6.5)$ and incubated for 24 hours at 37 ${ }^{\circ} \mathrm{C}$ against the test microorganisms. Subsequently, the susceptibility and resistance of each bacteria were determined by measuring the inhibition zone diameter (IZ) (0.6 mm disc diameter) around the wells. The antibiotic standard (Sigma-Oxytetracycline) was used to compare the results $(10 \mathrm{mg} / \mathrm{mL}$ antibiotic $100 \mu \mathrm{L}$ enject); $100 \mathrm{mg} / \mathrm{mL}$ - dry extract $100 \mu \mathrm{L}, 100 \mu \mathrm{L} / \mathrm{mL}$ - kefir extract $100 \mu \mathrm{L}$.

\subsection{Isolation of antimicrobial peptides for $L C-M S / M S$ in RP-HPLC}

Water-soluble fractions were separated according to their molecular size using centrifugal filters (Amicon Ultracel-3K, Merck-Millipore Ltd, Cork, Ireland). Since peptides showing bioactive properties are generally peptides containing 2-20 amino acids, peptide profile of peptides smaller than $3 \mathrm{kDa}$ was determined by RP-HPLC analysis and they were collected into separate fractions. The total peptide analysis for 80 minutes for fractionation is given in Figure 1b. Antimicrobial activity was examined in the fractions separated from the fraction collector. The peptide fraction named F2 was determined to have antimicrobial ctivity.

(a)

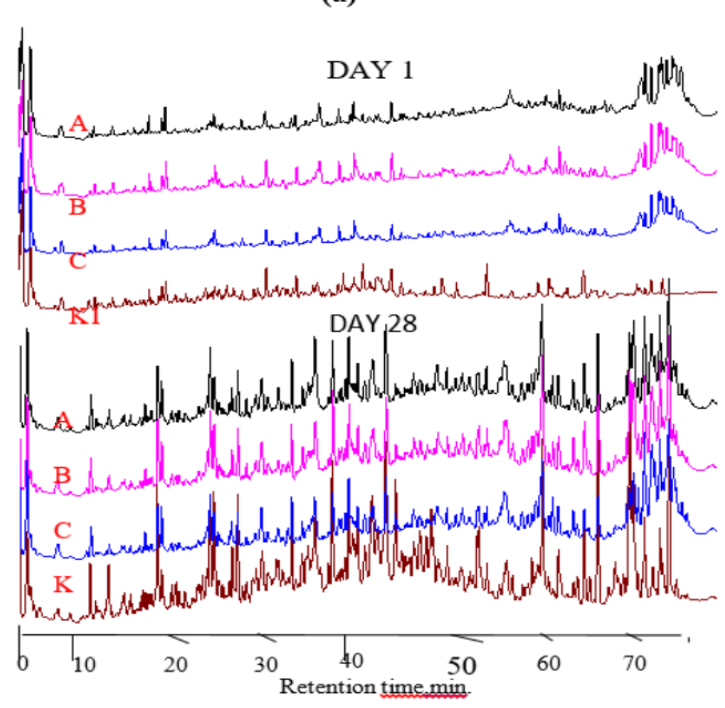

(b)

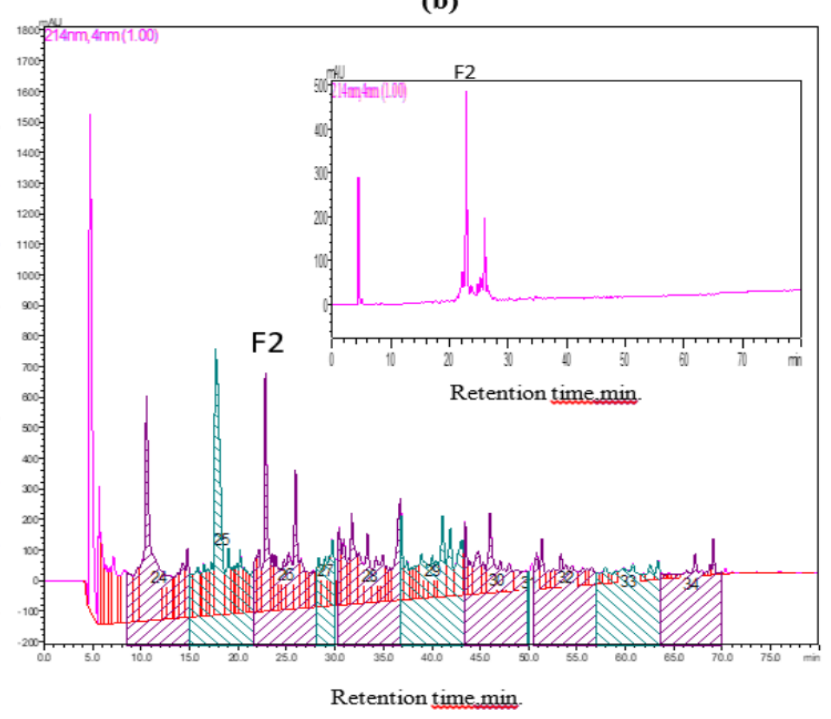

Figure 1- (a) RP-HPLC peptide profile of the kefir samples. Sample K, kefir granule containing; sample A: kefir granule+ $L$. bulgaricus; sample B: kefir granule+ L. helveticus; sample C: kefir granule+ L. plantarum. (Day 1, 28) (b) Separating peptide fractions of kefir that are less than $3 \mathrm{kDa}$ in HPLC fraction collector. F0, 8.50-15.17 min; F1, 15.20-21.60; F2, 21.70-28.18 min; F3, 28.22-30.00 min; F4, 30.25-36-82 min; F5, 36.83-43.38 min; F6, 43.40-49.88 min; F8-10, 50.45-70.00 min. 


\subsection{Characterization of antimicrobial peptides in LC-MS/MS}

Fractions were separated as shown in Figure $1 \mathrm{~b}$ and the F2 fraction with antimicrobial activity was analyzed under the conditions specified using liquid chromatography-mass spectrometry (LC-MS/MS) system (Shımadzu LC-MS 8030, Japan) with 0.1\% formic acid in $2 \%$ acetonitrile as the eluent. Fractions F2 was separated on a C18 reverse-phase capillary column (Agilent Technologies, Zorbax column, 4,6 $\times 250 \mathrm{~mm} \times 5 \mathrm{um}$ ). It was column oven $40{ }^{\circ} \mathrm{C}, 15 \mu \mathrm{L}$ sample was injected and a flow was set at $1 \mathrm{~mL} / \mathrm{min}$, with a linear gradient of eluent B ( $0.1 \%$ formic acid in $95 \%$ acetonitrile $)$ in A ( $0.1 \%$ formic acid in water) from 5 to $95 \%$ in $70 \mathrm{~min}$. The mass spectrometer was operated in the positive mode with a nebulizer pressure of max $60 \mathrm{MPa}$. Peptide analysis was performed using data-dependent acquisition of one MS scan (scan range from 100 to $1900 \mathrm{~m} / \mathrm{z}$, depending on the $\mathrm{m} / \mathrm{z}$ precursor ion) followed by a tandem MS (MS/MS) scan of the 5 most abundant ions in each MS scan.

\subsection{Statistical analysis}

An ANOVA followed by Duncan test was performed with a 95\% confidence, using the SPSS program (SPSS package program, version 13.0, SPSS Inc., USA). Data obtained from two trials were analyzed in duplicate, microbiological analyzes were analyzed in triplicate. Principal component analysis (PCA) was performed using a covariance matrix and varimax rotation between the kefirs (version 9.0, SPSS Inc., Chicago, IL). The results obtained were directly taken from automatic reporting in LCMS Lab solution Ver 5.72 without any further data manipulation except for the retention time adjustment and peak area integration review. For experimental parameters used the Class-Agent authentication database.

\section{Results and Discussion}

\subsection{The RP-HPLC peptide profiles of the kefirs}

RP-HPLC peptide profiles of days 1 and 28 of the Kefir samples are shown in Figure 1a. The RP-HPLC peptide profiles of the kefirs were precise and no significant discrepancy between the kefirs was detected. On the $28^{\text {th }}$ day of storage in sample $\mathrm{K}$, it was found out that almost no new peptides were reproduced with the except of certain ones. After the $28^{\text {th }}$ day of storage, presence of some peptides was detected in the sample $\mathrm{K}$ at the highest concentration point. However, some minor differences were observed depending on the storage period in RP-HPLC chromatograms of kefir samples. During storage, almost identical peptide profiles were observed in all the kefir samples. Peptide profiles of samples A, B and C were similar on all days of storage except for sample K (Figure 1a).

\subsection{The RP-HPLC free amino acid profiles of the kefirs}

RP-HPLC free amino acids profile and PCA diagram of RP-HPLC free amino acids of the kefir samples were given (Figure 2a and Table 1) at 1 and 28 days of storage. The level of free amino acids such as Gln, Gly, Thr, Asp, and Ser was higher in the control sample compared to other kefir samples. It was observed that the amount of Arg, Glu and Pro increased in at the end of the storage period. The content of Trp, Asn, Ala, Gly increased in samples B and K during storage. Val content decreased during the storage period while Ile content increased in samples B, C and K. Amino acids at the highest concentration in sample K (control) were Ala, Glu, Gly, Asp, Phe respectively while in kefir with adjunct lactobacilli were Ala, Pro, Arg, Leu, Lys. Glu and Lys as an antioxidative component were found (9.39 for $\mathrm{K}, 8.87 \mathrm{mg} / 100 \mathrm{~g}$ for B) to be present at a high concentration. It has been reported that the intensity of the scavenging activity of peptides could be affected by the hydrophobic amino acid number. In a study, the content of hydrophobic amino acids such as Lys, His and Arg contributed to Fe ${ }^{2+}$ chelating activity, while Met, Pro, Cys, Ala, Gly, Val and Leu have a higher radical scavenging ability (Zhu et al. 2013). The presence of lysine is believed to increase the antioxidant capacity of peptides (Huang et al. 2017). The other study was identified the antioxidative peptides included Glu and Lys amino acids in goat milk fermented by L. plantarum 60 (Chen et al. 2021). The added adjunct cultures have a pronounced effect on the free amino acid content of kefir samples. The Pro concentration had the highest value in sample C (L. plantarum), followed by sample A (L. delbrueckii subsp. bulgaricus) and sample B (L. helveticus). The presence of Pro, Lys and Arg amino acids at the C-terminal ends of ACE-I peptides is generally indicated to increase their bioactivity. Pan et al. (2005) found that antihypertensive peptide was formed in skimmed milk fermented with Lb. helveticus JCM1004 and that VPP and IPP peptides including proline had an effect on ACE-I activity. It is suggested that the bioactivity of antihypertensive peptides is due to the hydrophobicity and positively charged amino acids of the peptides in the structure, which are generally found (Pripp et al. 2004). Proline found the highest amount in the free amino acid composition of kefir samples formed of kefir grains applied to conventional milk (Ultra High Temperature) and certificated organic milk, while Ala, Asp, Lys, Arg and Cys is followed by Güler et al. (2016). It was reported that the presence of Try, Val, Lys, Met, Phe, Thr and Ile in kefir (Liutkevičius \& Šarkinas, 2004). In a study investigating the chemical properties of Norwegian kefir, it was stated that Glutamic acid has the highest value among free amino acids (Grønnevik et al. 2011). Proline and Glutamic acid had the highest amount of free amino acids; Alanine was the second most abundant amino acid in kefir produced using L. bulgaricus HP1 and L. helveticus MP12 (Simova et al. 2002). Leucine is classified as an essential amino acid that gives chance to determine the degree of proteolysis. Leu was found at the lowest amount in sample $\mathrm{K}$, the highest values of these amino acids were B added L. helveticus. In a study, it was reported that kefir sample supplemented L. helveticus MP12 which has high peptidase and aminopeptidase activity compared to Lactococcus species, have a unique amino acid profile as respect to control samples, and Leu, Ile, Val, Lys, Phe and Met levels 
were found to be 1.5 times higher (Simova et al. 2006). Enzyme systems with different culture types and proteolytic activities cause the degradation of peptides and result in different kinds and amounts of amino acids. Similarity to this study, it was reported that the principal amino acids of kefir produced either by grains or commercial kefir culture including lactobacillus culture were glutamic acid, alanine, proline, valine and the like (Gul et al. 2018; Ozcan et al. 2019). The results of the free amino acid analysis of the kefirs were subjected to basic component analysis (PCA) and the graph showing the results of the analysis is shown in Figure 2a). In the PCA graph, which analyzed the results of the storage on days 1, 7, 14, 21 and 28, it was determined that kefir had a distribution depending on the storage period, the addition of Lactobacillus, and that kefirs exhibited a different amino acid profile. It was found that L. plantarum was separated from the other kefir samples (circled in Figure 2a) and contained a higher concentration of amino acids than other kefir samples. Supplementation of L. helveticus H9 enhanced fermented milk acidification and proteolysis. These bacteria generally have high extracellular proteinase activities and thus release specific bioactive peptides during milk fermentation (Nielsen et al. 2009; Zhou et al. 2019). L. helveticus is known to have high proteolytic activity (Ahtesh et al. 2017). Proteolytic activity of L. plantarum and L. helveticus strain were evaluated by Beganović et al. (2013). The remarkable proteolytic activity of these strains is possibly due to their ability to release extracellular and intracellular proteases during fermentation (Indarmawan et al. 2016; Fang et al. 2018). The total FAAs levels increased due to storage period (Figure 2b). The use of Lactobacillus as an additional culture resulted in a significant increase in total FAAs levels due to proteolytic activity. It was determined that the kefir produced by Lactobacillus (Lb. plantarum and L. helveticus) adjunct starter has a total FAAs value that is higher than the control samples at the end of storage period.

Table 1- HPLC-Free amino acids of kefir samples (mg/100g kefir) storage at $4{ }^{\circ} \mathrm{C}$ in 1 and 28 days

\begin{tabular}{|c|c|c|c|c|c|c|c|c|c|c|}
\hline \multirow[b]{2}{*}{ Amino acids } & \multicolumn{4}{|c|}{$D A Y 1$} & \multicolumn{4}{|c|}{$D A Y 28$} & \multicolumn{2}{|c|}{ Statistics } \\
\hline & $A$ & $B$ & $C$ & $K$ & $A$ & $B$ & $C$ & $K$ & $P_{d}$ & $P_{s}$ \\
\hline ASP & 1.76 & 1.65 & 2.7 & 1.6 & 7.04 & 5.46 & 5.36 & 8.35 & $* * *$ & $* * *$ \\
\hline GLU & 2.65 & 1.38 & 2.57 & 9.65 & 7.53 & 7.18 & 9.15 & 9.39 & $* * *$ & $* * *$ \\
\hline ASN & 0.07 & 0.96 & 0.6 & 0.5 & 0.95 & 4.01 & 0.79 & 0.97 & $* *$ & $* * *$ \\
\hline SER & 0.4 & 0.35 & 2.69 & 3.08 & 3.8 & 0.33 & 4.45 & 5.08 & $* * *$ & $* * *$ \\
\hline GLN & 0.05 & 0.19 & 0.48 & 0.39 & 0.87 & 0.24 & 0.76 & 0.96 & $* * *$ & $* * *$ \\
\hline GLY & 0.24 & 1.99 & 2.04 & 1.84 & 5.67 & 6.06 & 7.14 & 9.09 & $* * *$ & $* * *$ \\
\hline HIS & 1.34 & 6.18 & 5.62 & 6.48 & 5.74 & 5.18 & 7.85 & 6.16 & $* * *$ & $* * *$ \\
\hline $\mathrm{ARG}$ & 1.11 & 2.41 & 2.39 & 2.06 & 8.54 & 3.14 & 11.81 & 1.46 & $* * *$ & $* * *$ \\
\hline THR & 3.63 & 1.67 & 2.61 & 1.85 & 4.37 & 2.08 & 2.3 & 1.89 & $* * *$ & $* * *$ \\
\hline ALA & 11.67 & 16.18 & 12.85 & 11.8 & 16.13 & 16.98 & 16.31 & 12.66 & $* * *$ & $* * *$ \\
\hline PRO & 5.51 & 2.95 & 4.75 & 3.93 & 7.7 & 5.58 & 12.35 & 4.89 & $* * *$ & $* * *$ \\
\hline TYR & 3.77 & 2.18 & 3.33 & 2.63 & 3.02 & 4.45 & 5.7 & 2.22 & $* * *$ & $* * *$ \\
\hline VAL & 6.35 & 5.92 & 6.86 & 5.46 & 4.32 & 2.2 & 0.62 & 2.39 & $* * *$ & $* * *$ \\
\hline MET & 0.65 & 1.69 & 0.21 & 1.84 & 6.1 & 4.76 & 2.15 & 3.72 & $* * *$ & $* * *$ \\
\hline CYS & 1.1 & 1.55 & 5.61 & 2.67 & 3.84 & 5.93 & 10.84 & 7.03 & $* * *$ & $* * *$ \\
\hline ILE & 0.45 & 0.4 & 0.6 & 0.38 & 0.57 & 4.97 & 2.31 & 3.32 & $* * *$ & $* * *$ \\
\hline LEU & 4.46 & 8.54 & 7.51 & 7.27 & 7.66 & 9.7 & 8.22 & 7.21 & $* * *$ & $* * *$ \\
\hline PHE & 0.33 & 5.97 & 2.76 & 6.79 & 7.41 & 6.14 & 3.22 & 7.38 & $* * *$ & $* * *$ \\
\hline TRP & 2.94 & 1.16 & 1.12 & 1.89 & 6.41 & 4.13 & 1.84 & 5.15 & $* * *$ & $* * *$ \\
\hline LYS & 2.41 & 4.53 & 5.67 & 4.01 & 3.21 & 8.87 & 7.07 & 6.41 & $* * *$ & $* * *$ \\
\hline TOTAL & 50.88 & 67.83 & 72.97 & 76.11 & 110.88 & 107.4 & 120.24 & 105.73 & $* * *$ & $* * *$ \\
\hline
\end{tabular}

$P$ probability; $* \mathrm{P}<0.05 ; * * \mathrm{P}<0.01 ; * * * \mathrm{P}<0.001 ; P_{d}$ : Day; $P_{s}$ : sample; sample K, kefir granule containing; sample A: kefir granule+ Lb. bulgaricus; sample B: kefir granule+ $L b$. helveticus; sample $\mathrm{C}$ : kefir granule+ $L b$. plantarum. 
(a)

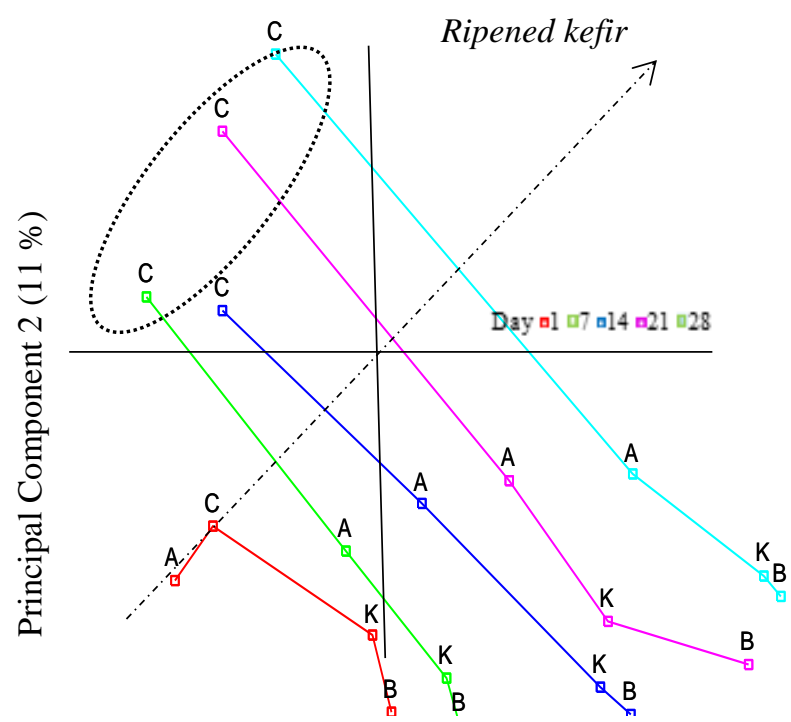

Principal Component $1(66 \%)$ (b)

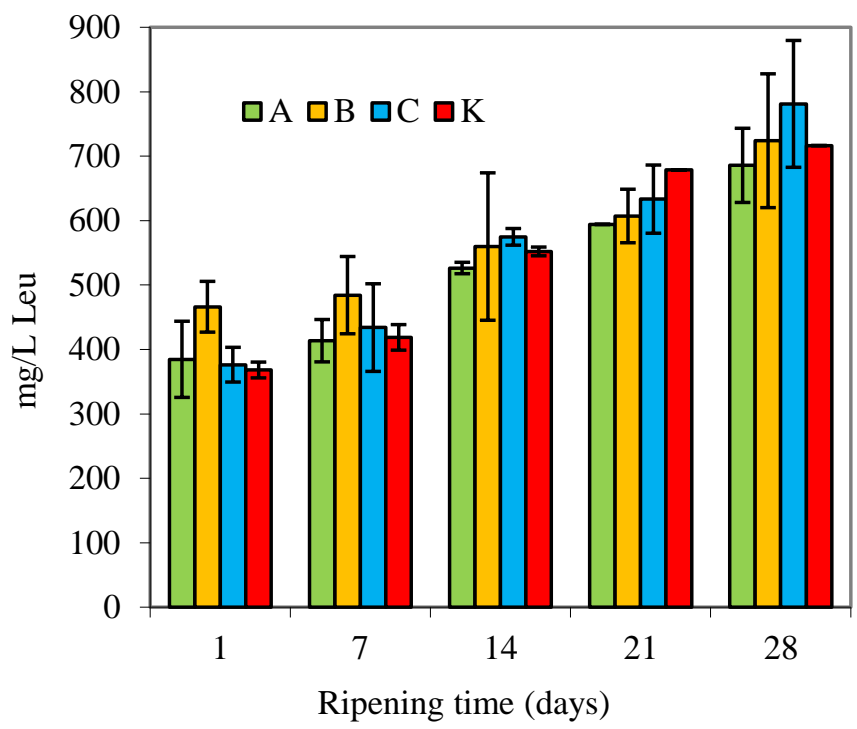

Figure 2- (a) PCA diagram of RP-HPLC Free Amino Acids from samples. Sample K, kefir granule containing; sample A: kefir granule + L. bulgaricus; sample B: kefir granule + L. helveticus; sample C: kefir granule + L. plantarum. (b) Total free amino acids of kefir samples (mg/L, Leu)

\subsection{ACE-I activities of kefir samples}

Fermented dairy products, such as yogurt, different types of cheese and kefir, contain peptides with ACE-I activity, these inhibitors are used to cure high blood pressure and hypertension (Shu et al. 2017). Proteins are hydrolyzed into plenty of bioactive peptides, antihypertensive activity, by lactic acid bacteria during fermentation especially lactobacilli is one of its important biofunctional properties. It was also found that ACE-I activity as $\mathrm{IC}_{50}$ was significantly increased in sample $\mathrm{C}(14.84 \pm 1.2 \mathrm{mg} / \mathrm{mL})$ and sample B $(16.73 \pm 0.02 \mathrm{mg} / \mathrm{mL}$ ) (Figure $3 \mathrm{a}, \mathrm{b})$. ACE-I activities and $\mathrm{IC}_{50}$ values of kefir samples were determined on days 1 , 7, 14, 21 and 28 of storage and the results were shown in Figure 3(a,b). The results were expressed as \% inhibition and $\mathrm{IC}_{50}$. With the progress of the storage period, it was found that the kefir had an increase in ACE-I activities and this increase was statistically significant $(\mathrm{P}<0.01)$. Sample B (including L. helveticus) showed strongest inhibition activity $(57.28 \% \pm 1.03)$ and $\mathrm{IC}_{50}$ value of $19.86 \pm 0.1 \mathrm{mg} / \mathrm{L}$ on the first day. The use of Lactobacillus bacteria in kefir production has been associated with a significant increase in ACE-I activity and it has been determined that the bacterium that maximizes ACE-I activity was $L$. plantarum. The highest ACE-I activity revealed that sample $\mathrm{C}$ on the 28 day and ACE-I activities of other samples was $76.47 \%$, $84.95 \%, 87.33 \%$ and $85.57 \%$ respectively. $\mathrm{IC}_{50}$ values between $30.27 \pm 1.13$ and $19.71 \pm 0.73 \mathrm{mg} / \mathrm{L}$. L. plantarum showed the strongest ACE-I activity of $87.33 \pm 0.67 \%\left(\mathrm{IC}_{50}=19.71 \pm 0.73 \mathrm{mg} / \mathrm{L}\right)$ on the last storage day. We may explain that higher ACE-I activity associated with an extensive proteolysis activity which may an increase in the intensity of peptides recognized as potential ACE inhibitors due to the adjunct culture addition especially lactobacilli. This limitation occurs once ACE-I activity depends on antihypertensive peptides' presence, which in turn relies on the balance between the release of bioactive peptides and the cleavage of these fractions in amino acids and inactive peptides (Ahiara et al. 2015; Rutella et al. 2016). Fermentation by lactic acid bacteria could positively contribute to ACE-I activity, as revealed in this study, and as reported by Aihara et al. (2005) who described an increase in activity following fermentation of powdered milk with L. helveticus. ACE-I activity showed a significant increase in milk fermented by L. plantarum K25 (Zhang et al. 2020). The addition of Lactobacillus may technological strategy that can be used in kefir processing to favor the bioactive potential of this product. Almost all the bioactive peptide sequences reported in many studies, including those displaying ACE-I activity, are derived from dairy products, especially fermented milk products, and classified as antihypertensive peptides. 
(a)

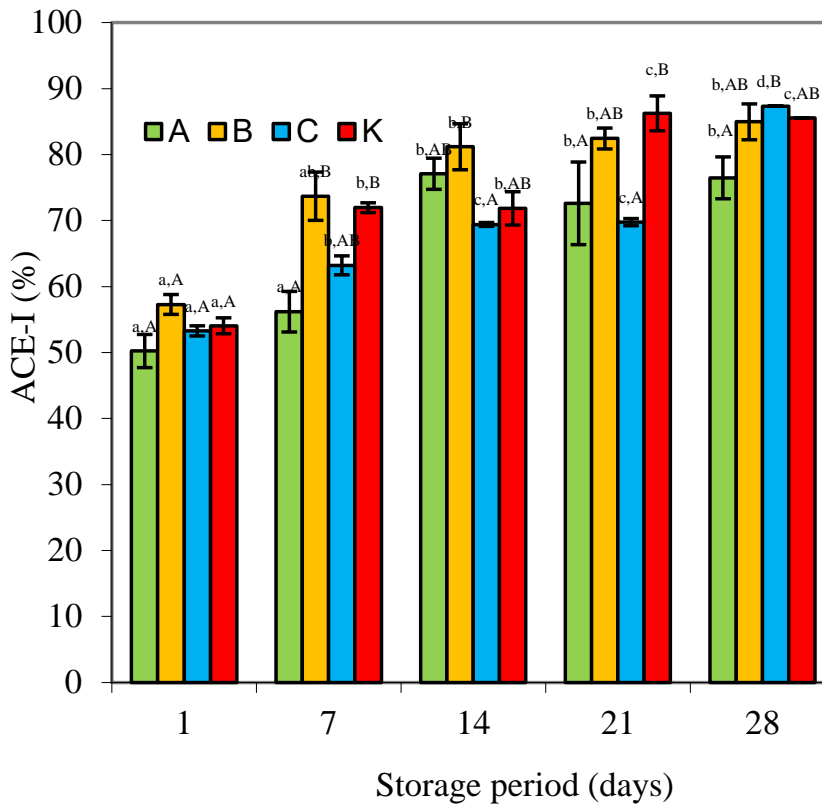

(b)

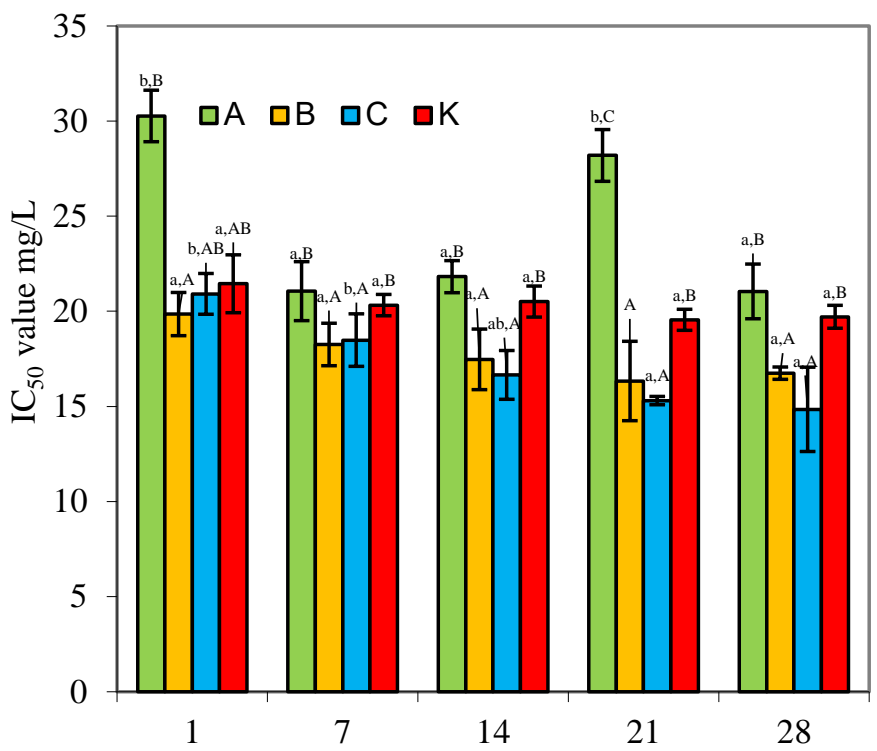

Storage period (days)

Figure 3- (a) ACE-I activity of Samples. sample K, kefir granule containing; sample A: kefir granule+ L. bulgaricus; sample B: kefir granule + L. helveticus; sample C: kefir granule + L. plantarum. 3 (b) IC $_{50}$ value (mg/L Bovine Serum Albumin) for ACE-I activity of kefir samples. The capital letters $A$ and $B$ indicate means that significantly differ at $P<0.01$ between samples kefir. The lower case letters a and $b$ indicate means that significantly differ at $P<0.01$ between days

\subsection{Determination of antimicrobial activity and characterization of antimicrobial peptide by LC/MS-MS}

Kefir contains several metabolites and inhibitors such as organic acid, peroxide hydrogen, ethyl alcohol, diacetyl, peptide, and bacteriocins. Antimicrobial activity is derived from lactic acid and other metabolites (Teneva et al. 2017). The metabolites are interacting to improve antimicrobial activity during kefir fermentation. The antimicrobial properties of kefir can be its metabolites produced by kefir microorganisms, such as exclusive peptides and exopolysaccharides (Kim et al. 2016). The indicator and pathogenic microorganisms were selected to determine the antimicrobial activity and disk diffusion test was used to certain the antimicrobial activity of the sample extracts (A, B and C) and lyophilized WSN fractions ( $<3 \mathrm{kDa})$. The antimicrobial effect against some microorganisms as inhibition zone diameter $(\mathrm{mm})$ of kefir extract and peptide fraction was given in Table 2. Kefir extract A, B and C showed broader spectrum antimicrobial activity, inhibiting S. aureus, S. warneri, S. xylosus, B. cereus, E. coli, E. fecalis, Enterobacter. Sample K (control), on the other hand, showed a narrower spectrum antimicrobial activity by inhibiting S. aureus, E. coli and E. fecalis. However, in the sample K, it set forth the finding that the proteolysis during the kefir fermentation is not high enough to form antimicrobial peptides. Also, the microbial diversity can be different in each fermentation process of kefir. Lactobacillus strains that are generally consumed as probiotics and these bacteria may possess antimicrobial activity. This study has shown that the peptide fraction ( $<3 \mathrm{k}$ Dda) from kefir fermented using Lactobacillus adjunct culture presented high inhibition of the growth of $S$. aureus, $S$. warneri and $S$. hominis from $28^{\text {th }}$ day of storage. The antimicrobial effect wasn't observed against $C$. albicans for all the kefir extract and peptide fractions in this study. Taşkın \& Akköprü (2020) was reported that the antimicrobial activity of kefir may be due to the antimicrobial substances present in the supernatants. It was reported that kefir possessed an antibacterial activity against E. coli D157: H7 and S. aureus (Kivanc \& Yapici 2018). In a study similar to, it was reported that kefir inhibited B. subtilis, S. aureus and E. faecalis and S. enteritidis but did not inhibit C. albicans (Chifiruc et al. 2011). The higher antibacterial activity of kefir supplemented with lactobacilli may be attributed to the hydrolysis of proteins and its contribution to antimicrobial peptide release by the enzymes of lactobacilli. It was reported that $L$. delbrueckii subsp bulgaricus has the antimicrobial activity against some of pathogenic bacteria including E. coli and Shigella. Presence of lactic acid along with the organic acids, bioactive peptides and bacteriocins may affect the antimicrobial activity of $L$. bulgaricus (Zaeim et al. 2014). Antimicrobial activity of $L$ plantarum against some patogenic bacteria has already been established. Antibacterial property of $L$. plantarum might be due to its ability production of antibacterial compounds, which may inhibit the growth of harmful and pathogenic bacteria (Monteiro et al. 2019). The microbial diversity is responsible for the biological activities depending on the amount and various of Lactobacillus in kefir, their microbial diversity is different, and therefore, its antibacterial activity also changes. It means that peptides produced by Lactobacillus are more in number than peptides produced by lactic acid bacteria. This result is strongly related to the type and amount of peptidases. To make use of casein in milk, lactic acid bacteria firstly hydrolyze casein into oligopeptides by cell wall proteases and then transport it into cells through a specific oligopeptide transport system, further degrading oligopeptides into smaller peptides and amino acids by intracellular peptidases to provide for the growth and utilization of bacteria. At the same time, intracellular peptides are not only from casein hydrolysis, but also from the Lactobacillus itself because of existing bacteria protein degradation (Savijoki et al. 2006). Additionally, to pharmaceutical drugs, without side effects bioactive peptides considered as alternatives daily with a variety of protein-rich foods can be consumed. Bioactive peptides as potent natural ingredients it will contribute to its use in foods. Firstly, separation and detection of antimicrobial peptides should be done in kefir 
metabolomics. It is important to investigate this mechanism. Additionally, future studies will focus on sequences of peptides identified in these fractions.

Separation of antimicrobial peptides was analyzed by HPLC. HPLC is a widely used method for the purification of peptides (Ahn et al. 2014; Zheng et al. 2018). The F2 fraction was further separated using HPLC. The chromatographic profile was given in Figure 1b. Total eight fractions were obtained and numbered sequentially F1-8. The antimicrobial activity of the F2 fraction was determined and the results were given (Table 2). F2 fraction had strong antimicrobial activity and no antimicrobial activity was observed in other fractions. Therefore, an attempt was made to determine the peptide characterization of the F2 fraction. In this report, we examined the MS/MS spectra of the protein fractions. The peptide fraction named $\mathrm{F} 2$ was determined to have been an antimicrobial inhibitory activity against three bacteria $(S$. hominis, S. warneri and S. aureus) and was collected from RP-HPLC. The peptide characterization was obtained by direct LC-MS/MS measurement in the $\mathrm{m} / \mathrm{z}$ range from 100 to $1900 \mathrm{Da}$. The tuning of peptides was performed through continuous infusion of standards into ESI (positive electrospray ionization) mode source in positive mode at a flow rate of $10 \mu \mathrm{L} / \mathrm{min}$. We reported the product and precursor ions by determining the $\mathrm{m} / \mathrm{z}$ value of the peptide fractions that had an antimicrobial effect on $S$. aureus, S. warneri and $S$. hominis. Total ion spectra by LC-MS/MS of fraction 2 with three major peaks was given in Figure $4 \mathrm{a}$ and $4 \mathrm{~b}$ for samples A, B and C. Considering the comparison with Figure 4a ve Figure 5, we can see that the peaks of A and C are larger in amount than B and K. The Q3 mass was predominant among the full scan of protonated precursors and the product ions of precursor ions were monitored further. The product ion scan yielded the following predominant fragment ions at $\mathrm{m} / \mathrm{z}$ values 339.381 and 308 for precursor ions for samples A, B and C (Figure 5).

Bioactivity of protein fractions is related to amino acid composition, sequence, size and configuration of peptides (Rutella et al. 2016). Future studies will focus on sequences of peptides identified in this fraction.

Table 2 (a)-Antibacterial activity of peptide fractions (F2) in term of inhibition zone (IZ) in mm (b)Antibacterial activity of sample extract in term of inhibition zone (IZ) in $\mathbf{m m}$

\begin{tabular}{|c|c|c|c|c|c|c|c|c|c|c|}
\hline \multirow[t]{2}{*}{ Bacteria } & \multicolumn{2}{|c|}{$\boldsymbol{A}$} & \multicolumn{2}{|c|}{$\boldsymbol{B}$} & \multicolumn{2}{|c|}{$C$} & \multicolumn{2}{|c|}{$\boldsymbol{K}$} & \multicolumn{2}{|c|}{ Oxytetracycline } \\
\hline & (a) & (b) & (a) & (b) & (a) & (b) & (a) & (b) & (a) & (b) \\
\hline S. epidermidis & - & - & - & - & - & - & - & - & +++ & +++ \\
\hline S. aureus & + & ++ & + & ++ & + & ++ & - & + & ++ & ++ \\
\hline S. warneri 95052 & - & + & + & ++ & - & + & - & - & + & + \\
\hline S. xylosus & - & ++ & - & +++ & - & ++ & - & - & +++ & +++ \\
\hline S. flexneri RSKK 184 & - & - & - & - & - & - & - & - & + & + \\
\hline B. cereus $R S 863$ & - & + & - & + & - & - & - & - & +++ & +++ \\
\hline E. coli & - & ++ & - & ++ & - & ++ & - & + & ++ & ++ \\
\hline E. faecalis & - & ++ & - & ++ & - & ++ & - & ++ & ++ & ++ \\
\hline C. albicans ATCC 04055 & - & - & - & - & - & - & - & - & ND & ND \\
\hline Str. mutans & - & - & - & - & - & - & - & - & +++ & +++ \\
\hline Enterobacter & - & + & - & + & - & - & - & - & +++ & +++ \\
\hline S. enteritidis & - & - & - & + & - & - & - & - & +++ & +++ \\
\hline S. hominis & - & - & - & - & ++ & - & - & - & +++ & +++ \\
\hline
\end{tabular}

Sample K, kefir granule containing; sample A: kefir granule + L. bulgaricus; sample B: kefir granule + L. helveticus; sample C: kefir granule+ L. plantarum. (+) inhibition positive; (+) inhibition diameter 4-10 mm; (++) inhibition diameter 11-19 mm; (+++) inhibition diameter greater than 20 mm; (-) Inhibition negative. 
(4a)
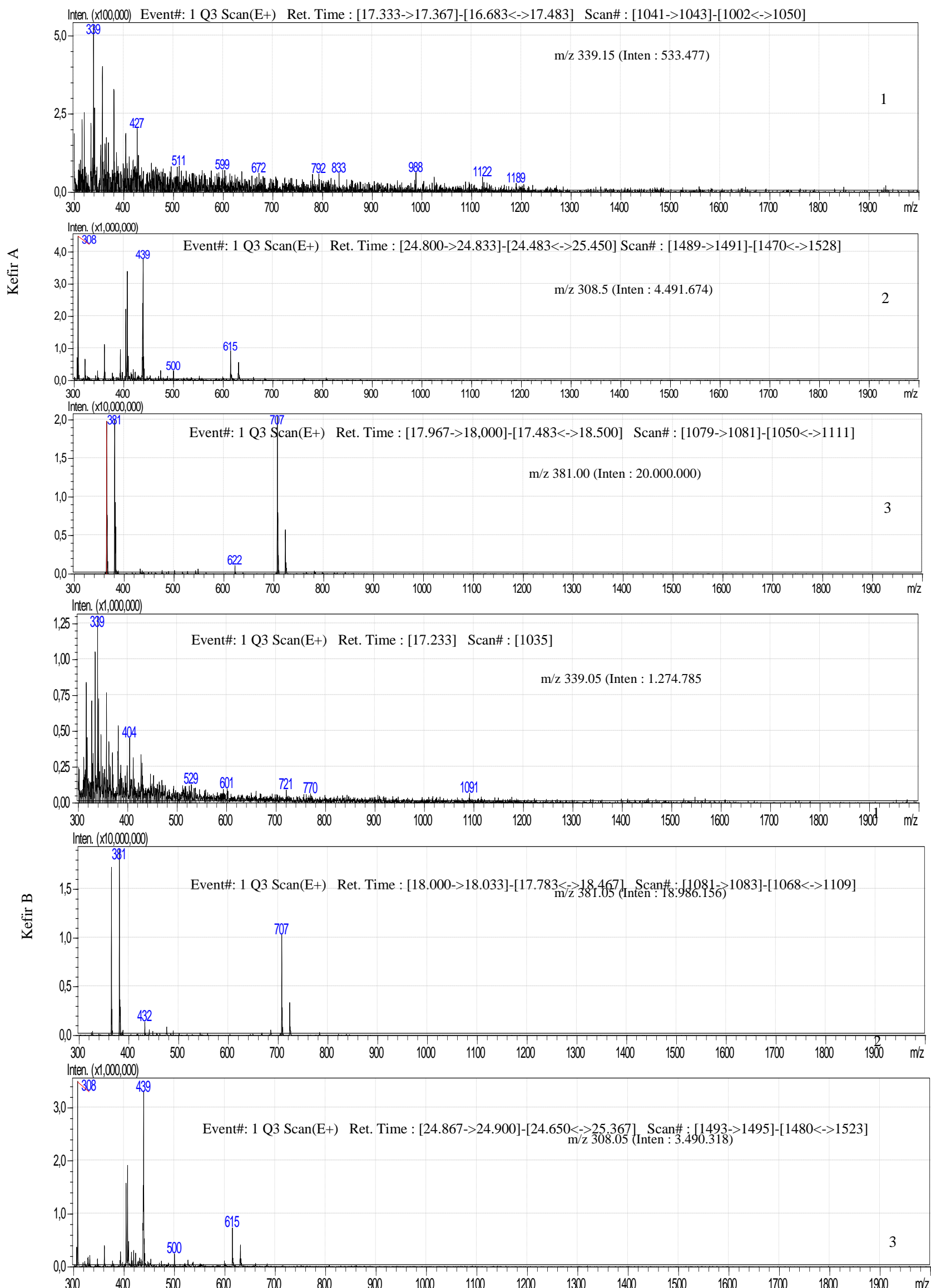
(4b)

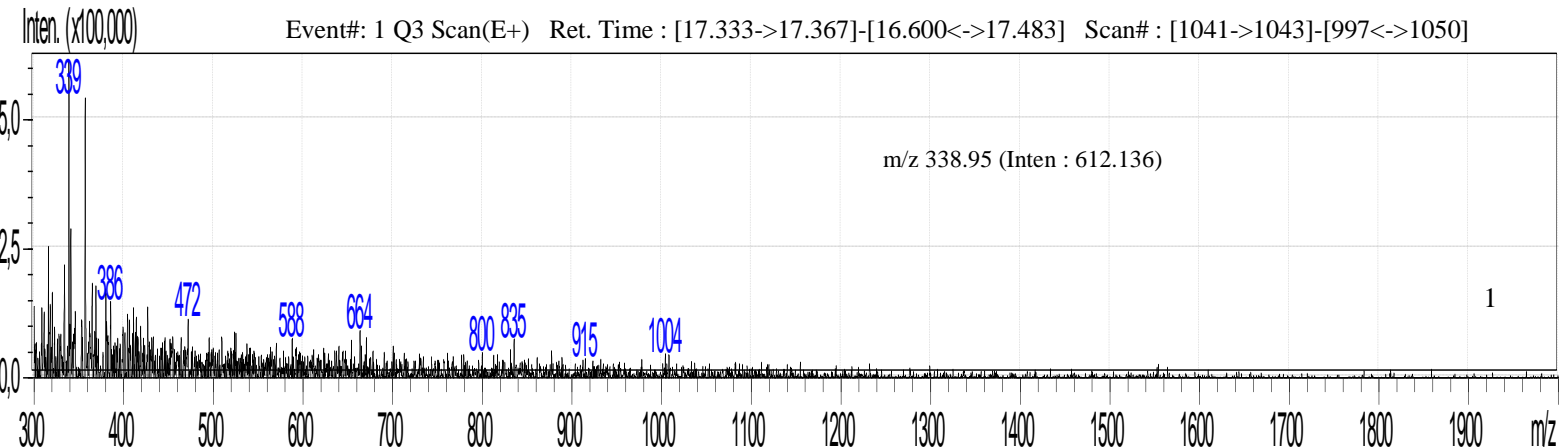
Inten. $1 \times 10,000,000$

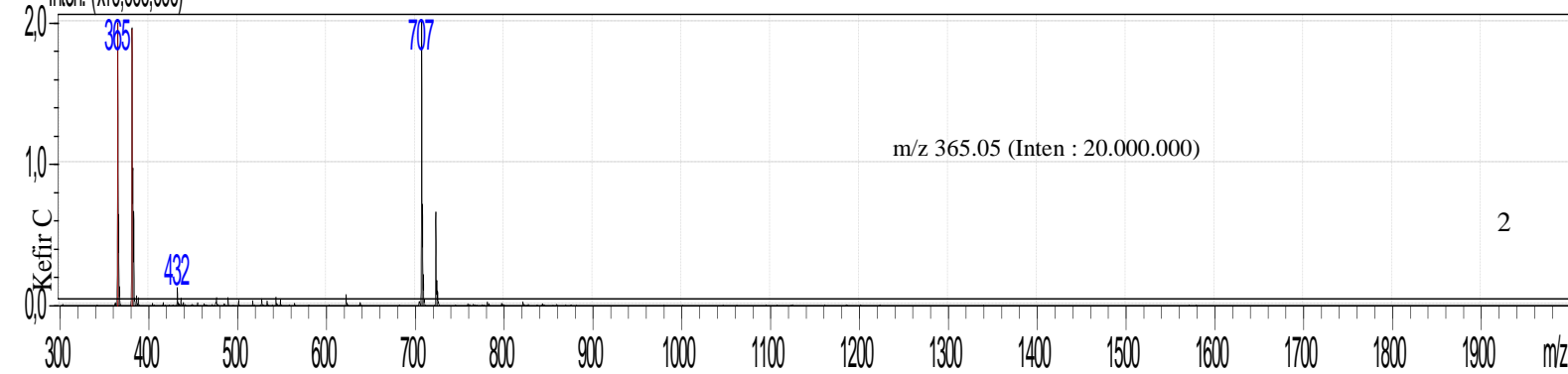

\section{Inten, $(X \mid, O O O,, O O O) \quad$ Event\#: 1 Q3 Scan(E+) Ret. Time : [24.833->24.867]-[24.500<->25.433] Scan\# : [1491->1493]-[1471<->1527]}

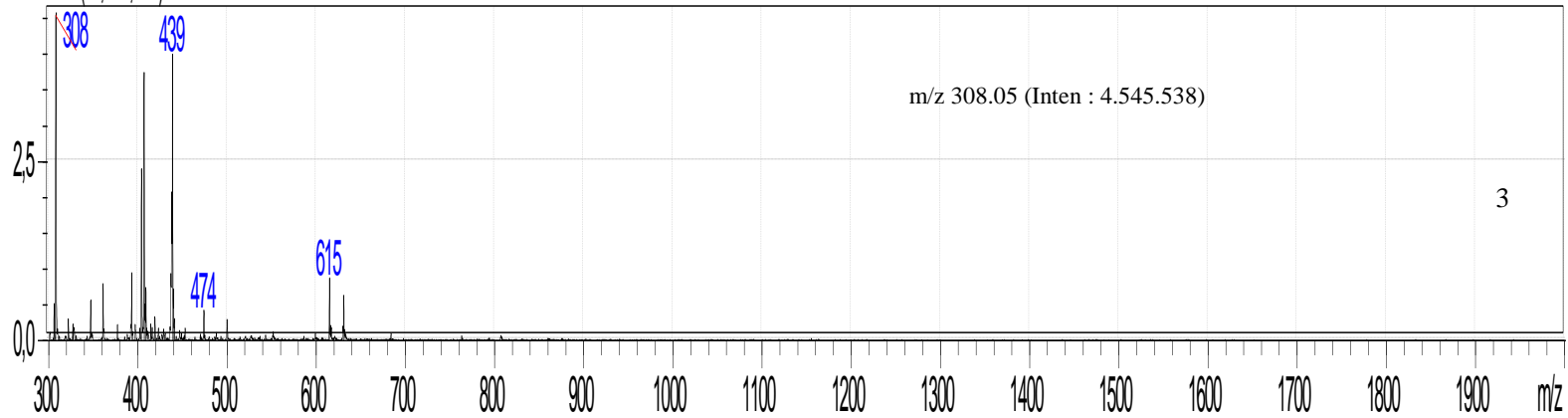

Figure 4- (a) Intensity chromatogram of LCMS/MS spectrum of ions from fraction 2 in sample A; Intensity chromatogram of LCMS/MS spectrum of ions from fraction 2 in sample B. (b) Intensity chromatogram of LCMS/MS spectrum of ions from fraction 2 in sample $C$. 

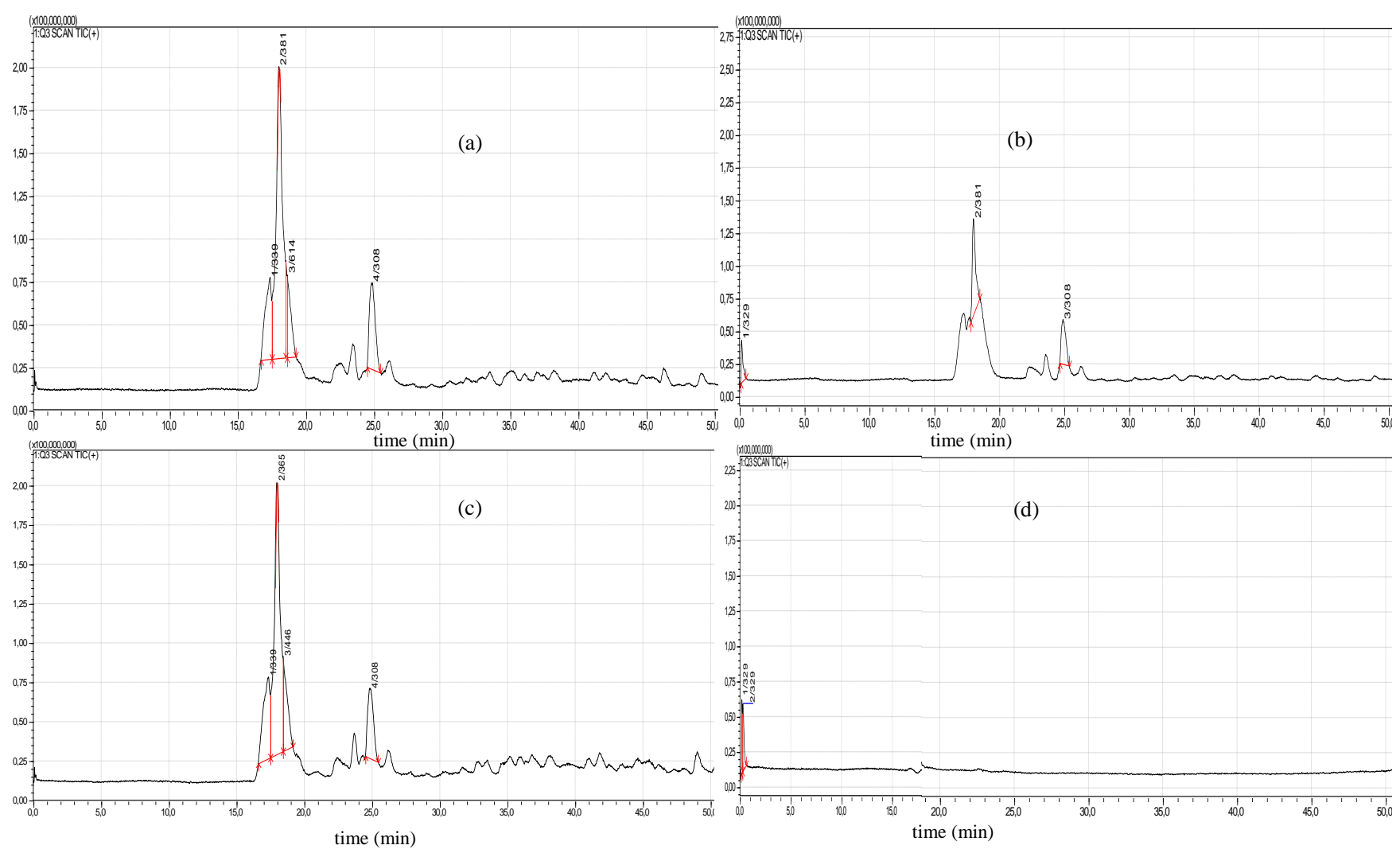

Figure 5- Illustrates total ion chromatogram of fraction 2 with three major peaks. The MS/MS spectrum of peak 1 at 339 m/z, peak 2 at $381 \mathrm{~m} / \mathrm{z}$ in where the ion of $381 \mathrm{~m} / \mathrm{z}$ was the most abundant for samples $B$ and $A$, peak 3 at $308 \mathrm{~m} / \mathrm{z}$ was shown. The

MS/MS spectrum of peak 1 at $339 \mathrm{~m} / \mathrm{z}$, peak 2 at $365 \mathrm{~m} / \mathrm{z}$ in where the ion of $381 \mathrm{~m} / \mathrm{z}$ was the most abundant for $C$ kefir samples, peak 3 at 308 m/z was shown (a) kefir granule + L. bulgaricus; (b) kefir granule + L. helveticus; (c) kefir granule + L. plantarum, (d) kefir granule containing

\section{Conclusions}

As a result, the use of adjunct culture in addition to kefir grains obtained better results than the traditional kefir method (produced with kefir grains alone) in terms of proteolysis and bioactive properties. The results show that the ACE-I activity was higher in kefir samples that produced Lactobacillus adjunct cultures. It was determined that the peptide fractions (for fraction F2) of the kefir samples produced by the addition of Lactobacillus have an antimicrobial effect compared with peptide fractions of sample $\mathrm{K}$. In addition, characterization of the peptide fraction named F2, which has antimicrobial activity against $S$. hominis, S. warneri and $S$. aureus, was achieved by LC-MS/MS. These findings supported that the kefir which probiotic fermented product has shown antihypertensive potential as a functional food and indicated application of the peptides as bio-preservative. The shelf life of food products can be extended by using these antimicrobial metabolites produced by selected microorganisms.

\section{Acknowledgments}

The authors thank Prof. Dr. Ali Adnan HAYALOGLU for providing the indicator strains used for the antibacterial activity assay and peptides characterization in LC-MS/MS

\section{Financial Support}

This study was financially supported by Scientific and Research Project Units of Inonu University, Malatya, Turkey with project number FYL-2017-728.

\section{References}

Ahn C, Kim J \& Je J (2014). Purification and antioxidant properties of octapeptide from salmon by product protein hydrolysate by gastrointestinal digestion. Food Chemistry 147: 78-83. https://doi.org/10.1016/j.foodchem.2013.09.136

Aihara K, Kajimoto O, Hirata H, Takahashi R \& Nakamura Y (2005). Effect of powdered fermented milk with Lactobacillus helveticus on subjects with high-normal blood pressure or mild hypertension. Journal of the American College of Nutrition 24(4): 257-265. https://doi.org/10.1080/07315724.2005.10719473 
Ajam F \& Koohsari H (2020). Effect of some fermentation conditions on antibacterial activity of fermented milk by kefir grains. Journal Food Processing and Preservation 44(12): 1-14. https://doi.org/10.1111/jfpp.14913

Ahtesh F B, Stojanovska L \& Apostolopoulos V (2017). Processing and sensory characteristics of a fermented low-fat skim milk drink containing bioactive antihypertensive peptides, a functional milk product. International Journal Dairy Technology 70: 1-10. https://doi.org/10.1111/1471-0307.12479

Beganović J, Kos B, Pavunc A L, Uroić K, Džidara P \& Šušković J (2013). Proteolytic activity of probiotic strain Lactobacillus helveticus M92. Anaerobe 20: 58-64. https://doi.org/10.1016/j.anaerobe.2013.02.004

Chandra P \& Vij S (2018). Molecular Characterization and Identification of Bioactive Peptides Producing Lactobacillus sps. Based on 16S rRNA Gene Sequencing. Food Biotechnology 32(1): 1-14. https://doi.org/10.1080/08905436.2017.1413657

Chandra P, Sharma R K \& Singh Arora D (2019). Antioxidant compounds from microbial sources: A review. Food Research International, 129: 108849. https://doi.org/10.1016/j.foodres.2019.108849

Chen L, Hui Y, Gao T, Shu G \& Chen H (2021). Function and characterization of novel antioxidant peptides by fermentation with a wild Lactobacillus plantarum 60. LWT-Food Science and Technology 135: 110162. https://doi.org/10.1016/j.lwt.2020.110162

Fang K, Jin X \& Hong S H (2018). Probiotic Escherichia coli inhibits biofilm formation of pathogenic E. coli via extracellular activity of DegP. Scientific reports 8(1): 4939. https://doi.org/10.1038/s41598-018-23180-1

Garofalo C, Osimani A, Milanovic V, Aquilanti L, De Filippis F, Stellato G \& Clementi F (2015). Bacteria and yeast microbiota in milk kefir grains from different Italian regions. Food Microbiology, 49 (7): 123-133. https://doi.org/10.1016/j.fm.2015.01.017

Gobbetti M, Stepaniak L \& De Angelis (2002). Latent bioctive peptides in milk proteins: Proteolytic activation and significance in dairy processing. Critical Reviews in Food Science and Nutrition 42(3): 223-239. https://doi.org/10.1080/10408690290825538

Grønnevik H, Falstad M \& Narvhus J A (2011). Microbiological and chemical properties of Norwegian kefir during storage. International Dairy Journal 21(9): 601-606. https://doi.org/10.1016/j.idairyj.2012.03.005

Gul O, Atalar I, Mortas M \& Dervisoglu M (2018). Rheological, textural, colour and sensorial properties of kefir produced with buffalo milk using kefir grains and starter culture: A comparison with cows' milk kefir. International Journal Dairy Technology 71: 73-80. https://doi.org/10.1111/1471-0307.12503

Güler Z, Tekin A \& Park W Y (2016). Comparison of biochemical changes in kefir produced from organic and conventional milk at different inoculation rates of kefir grains. Journal of Food Science and Nutrition Therapy 2(1): 8-14. https://doi.org/10.17352/jfsnt.000003

Hayaloglu A A (2007). Comparison of different single-strain starter cultures for their effects on ripenig and grading of Beyaz cheese. Int $\mathbf{J}$ Food Science and Technology 42(8): 930-938. https://doi.org/10.1111/j.1365-2621.2006.01312.x

He B, Ma S, Peng G \& He D (2018). TAT-modified self-assembled cationic peptide nanoparticles as an efficient antibacterial agent. Nanomedicine: Nanotechnol, Bio and Med, 14(2): 365-372. https://doi.org/10.1016/j.nano.2017.11.002

Huang Y, Ruan G, Qin Z, Li H \& Zheng Y (2017). Antioxidant activity measurement and potential antioxidant peptides exploration from hydrolysates of novel continuous microwave-assisted enzymolysis of the Scomberomorus niphonius protein. Food Chemistry 223: 89-95. https://doi.org/10.1016/j.foodchem.2016.12.026

Indarmawan T, Mustopa A Z, Budiarto B R \& Tarman K (2016). Antibacterial activity of extracellular protease isolated from an algicolous fungus Xylaria psidii KT30 against gram-positive bacteria. Hayat Journal of Biosciences 23(2): 73-78. https://doi.org/10.1016/j.hjb.2016.06.005

Karacalı R, Ozdemir N \& Con A H (2018). Aromatic and functional aspects of kefir produced using soya milk and Bifidobacterium species. International Journal Dairy Technology 71(4): 921-933. https://doi.org/10.1111/1471-0307.12537

Karami Z \& Akbari-Adergani B (2019). Bioctive food derived peptides: a review on correlation between structure of bioactive peptides and their functional properties. Journal Food Science and Technology 56(2): 535-547. https://doi.org/10.1007/s13197-018-3549-4

Kim D H, Jeong D, Kim H, Kang I B, Chon J W, Song K \& Seo K H (2016). Antimicrobial activity of kefir against various food pathogens and spoilage bacteria. Korean Journal for Food Science of Animal Resources 36(6): 787-790. https://doi.org/10.5851/kosfa.2016.36.6.787

Kivanc M \& Yapici E (2018). Survival of Escherichia coli O157: H7 and Staphylococcus aureus during the fermentation and storage of kefir. Food Sci and Technol (Campinas) 39(1): 225- 230. https://doi.org/10.1590/fst.39517

Kunji E R S, Mierau I, Hagting A \& Poolman W N (1996). Konings The proteolytic systems of lactic acid bacteria. Antonie Van Leeuwenkoek 70: 187-221

Liutkevičius A \& Šarkinas (2004). Studies on the growth conditions and composition of Kefir grains-as a food and forage biomass. Dairy Sicence Abstracts 66: 903

Ma B, Guo Y, Fu X \& Jin Y (2020). Identification and antimicrobial mechanisms of a novel peptide derived from egg white ovotransferrin hydrolysates. LWT - Food Science and Technology 131: 109720. https://doi.org/10.1016/j.lwt.2020.109720

Maeda H, Zhu X, Suzuki S, Suzuki K \& Kitamura S (2004). Structural characterization and biological activities of an exopolysaccharide kefiran produced by Lactobacillus kefiran of aciens WT-2B (T). Journal of Agricultural and Food Chemistry 52(17): 5533-5538. https://doi.org/10.1021/jf049617g

Miao J, Guo H, Chen F, Zhao L \& He L (2016). Antibacterial effects of a cell penetrating peptide isolated from kefir. Journal of Agricultural and Food Chemistry 64(16): 3234-3242. https://doi.org/10.1021/acs.jafc.6b00730

Monteiro C, Carmo M do, Melo B, Alves M, dos Santos C, Monteiro S, Bomfim M, Fernandes E \& Monteiro-Neto V (2019). In vitro antimicrobial activity and probiotic potential of bifidobacterium and lactobacillus against species of clostridium. Nutrients 11(2):448. https://doi.org/10.3390/nu11020448

Nielsen M S, Martinusen T, Flambard B, Sorensen K I \& Otte J (2009). Peptide profiles and angiotensin-I-converting enzyme inhibitory activity of fermented milk products: effect of bacterial strain, fermentation $\mathrm{pH}$ and storage time. International Dairy Journal 19(3): 155165. https://doi.org/10.1016/j.idairyj.2008.10.003

Otte J, Lenhard T, Flambard B \& Sorensen (2011). Influence of fermentation temperature and autolysis on ACE-I activity and peptide profiles of milk fermented by selected strains of Lactobacillus helveticus and Lactococcus lactis. International Dairy Journal 21(4): 229-238

Ozcan T, Sahin S, Akpınar-Bayızit A \& Y1lmaz-Ersan L (2019). Assessment of antioxidant capacity by method comparison and amino acid characterisation in buffalo milk kefir. International Journal of Dairy Technology 72(1):65-73. https://doi.org/10.1111/1471-0307.12560

Pan D, Luo Y \& Tanokura M (2005). Antihypertensive peptides from skimmed milk hydrolysate digested by cell-free extract of Lactobacillus helveticus JCM1004. Food Chemistry 91: 123-129. https://doi.org/10.1016/j.foodchem.2004.05.055

Pihlanto-Leppälä A (2000). Bioactive peptides derived from bovine whey proteins: Opioid and ACE-I peptides. Trends in Food Science and Technology 11(9-10): 347-356. https://doi.org/10.1016/s0924-2244(01)00003-6 
Pina-Perez M C, Rodrigo D \& Martinez A (2015). Using natural antimicrobials to enhance the safety and quality of milk. In M. Taylor (Ed.). Handbook of natural antimicrobials for food safety and quality Elsevier Ltd. 327-340.

Pogačić T, Šinko S, Zamberlin Š \& Samaržija D (2013). Microbiota of kefir grains. Mljekarstvo 63(1):3-14

Pripp A H, Isaksson T, Stepniak L, Sorhaug T (2004). Quantitative structure-activity relationship modelling of ACE-inhibitory peptides derived from milk proteins. European Food Research and Tehcnology 219(6): 579-583. https://doi.org/10.1007/s00217-004-1004-4

Prado M R, Blandon L M, Vandenberghe L P S, Rodrigues C, Castro G R, Soccol1 V T \& Soccol1 C R (2015). Milk kefir: Composition, microbial cultures, biological activities, and related products. Frontiers in Microbiology 6: 1-10. https://doi.org/10.3389/fmicb.2015.01177

Purutoglu K, Ispirli H, Yuzer M O, Serencam H \& Dertli E (2020). Diversity and functional characteristics of lactic acid bacteria from traditional kefir grains. International Journal of Dairy Technology 73(1): 57-66. https://doi.org/10.1111/1471-0307.12633

Quiros A, Hernandez-Ledesma B, Ramos M, Amigo L \& Recio I (2005). Angiotensin-converting enzyme inhibitory activity of peptides derived from caprine Kefir. Journal Dairy Science 88(10): 3480-3487. https://doi.org/10.3168/jds.s0022-0302(05)73032-0

Rutella G S, Tagliazucchi D \& Solieri L (2016). Survival and bioactivities of selected probiotic lactobacilli in yogurt fermentation and cold storage: New insights for developing a bi-functional dairy food. Food Microbiology 60: 54-61. https://doi.org/10.1016/j.fm.2016.06.017.

Sahingil D, Gokce Y, Yuceer M \& Hayaloglu A A (2019). Optimization of proteolysis and angiotensin converting enzyme inhibition activity in a model cheese using response surface methodology. LWT-Food Science and Techonology 99:525-532. https://doi.org/10.1016/j.lwt.2018.09.076

Sanlı T, Akal H C, Yetisemiyen H \& Hayaloglu A A (2018). Influence of adjunct cultures on angiotensin-converting enzyme (ACE)-inhibitory activity, organic acid content and peptide profile of kefir. International Journal Dairy Technology 71(1):131-139. https://doi.org/10.1111/1471-0307.12346

Savijoki K, Ingmer H \& Varmanen P (2006). Proteolytic systems of lactic acid bacteria. Applied Microbiology Biotechnology 71: $394-406$. https://doi.org/10.1007/s00253-006-0427-1

Schanbacher F L, Talhouk R S, Murray F A, Gherman L I \& Willet L B (1998). Milk-born bioactive peptides. International Dairy Journal 8(56): 393-403

Shu G, Shi X, Chen H, Ji Z \& Meng J (2017). Optimization of goat milk with ACE-Ipeptides fermented by Lactobacillus bulgaricus lb6 using response surface methodology. Molecules 22(11): 2001. https://doi.org/10.3390/molecules22112001

Simova E, Beshkova D, Angelov A, Hristozova T, Frengova G \& Spasov Z (2002). Lactic acid bacteria and yeasts in kefir grains and kefir made from them. Journal of Industrial Microbiology and Biotec 28: 1-6

Simova E, Simov Z, Beshkova D, Frengova G, Dimitrov Z \& Spasov Z (2006). Amino acid profiles of lactic acid bacteria, isolated from kefir grains and kefir starter made from them. International Journal of Food Microbiology 107(2): 112-123. https://doi.org/10.1016/j.ijfoodmicro.2005.08.020

Sulejmani E \& Hayaloglu A A (2017). Characterisation of Macedonian White brined cheese: Effect of raw or heat-treated caprine milk. International Journal Dairy Technology 71(2): 408-416. https://doi.org/10.1111/1471-0307.12486

Sundin G W \& Wang N (2018). Antibiotic Resistance in Plant-Pathogenic Bacteria. Annual Review of Phytopathology 56: 161-180. https://doi.org/10.1146/annurev-phyto-080417-045946

Tas T K, Ekinci F Y \& Guzel-Seydim Z B (2012). Identification of microbial flora in kefir grains produced in Turkey using PCR. International Journal Dairy Technology 65(1): 126-131. https://doi.org/10.1111/j.1471-0307.2011.00733.x

Taşkın B \& Akköprü A (2020). Antibacterial Activity of Different Kefir Types Against Various Plant Pathogenic Bacteria. Journal of Agricultural Sciences 26: 316-323. https://doi.org/10.15832/ankutbd.499790

Teneva D, Denkova R, Goranov B, Denkova Z \& Kostov G (2017). Antimicrobial activity of Lactobacillus plantarum strains against Salmonella pathogens. Ukrainian Food Journal 6(1): 125-133. https://doi.org/10.24263/2304-974x-2017-6-1-14

Upendra R S, Khandelwal P, Jana K, Ajay Kumar N, Gayathri Devi M \& Stephaney M L (2016). Bacteriocin production from indigenous strains of lactic acid bacteria isolated from selected fermented food sources. International Journal Pharma Reseurce Health Sci 4(1): $982-990$

Wang H, Sun X M, Song X, Guo \& M R (2021) Effects of kefir grains from different origins on proteolysis and volatile profile of goat milk kefir. Food Chemistry 339: 128099. https://doi.org/10.1016/j.foodchem.2020.128099

Witthuhn R C, Schoeman T \& Britz T J (2004). Isolation and characterization of the microbial population of different South African kefir grains. International Journal Dairy Technology 57(1): 33-37. https://doi.org/10.1111/j.1471-0307.2004.00126.x

Zaeim D, Soleimanian-Zad S \& Sheikh-Zeinoddin M (2014). Identification and partial characterization of a bacteriocin-like inhibitory substance (BLIS) from Lb. bulgaricus K41 isolated from indigenous yogurts. Journal of Food Science 79(1):67-73. https://doi.org/10.1111/1750-3841.12314

Zajsek K \& Gorsek A (2011). Experimental assessment of the impact of cultivation conditions on kefiran production by the mixed microflora imbedded in kefir grains. Chemical Engineering Transactions 24: 481-486 2011. https://doi.org/10.1016/j.foodchem.2012.11.142

Zhang M, Jiang Y, Cai M \& Yang Z (2020). Characterization and ACE-I activity of fermented milk with probiotic Lactobacillus plantarum K25 as analyzed by GC-MS based metabolomics approach. Journal of Microbiology and Biotechnology 30(6): 903-911. https://doi.org/10.4014/jmb.1911.11007

Zheng Z, Si D, Ahmad B, Li Z \& Zhang R (2018). A novel antioxidative peptide derived from chicken blood corpuscle hydrolysate. Food Research International 106: 410-419. https://doi.org/10.1016/j.foodres.2017.12.078

Zhou T, Huo R, Kwok L Y, Li C, Ma Y \& Mi Z (2019). Effects of applying Lactobacillus helveticus H9 as adjunct starter culture in yogurt fermentation and storage. Journal of Dairy Science 102: 223-235. https://doi.org/10.3168/jds.2019-102-2-1885

Zhu B, He H \& Hou T (2019). A comprehensive review of corn protein-derived bioactive peptides: production, characterization, bioactivities, and transport pathways. Comprehensive Reviews Food Sci and Food Safety 18: 329-345. https://doi.org/10.1111/1541-4337.12411

Zhu C Z, Zhang W G, Zhou G H, Xu X L, Kang Z L \& Yin Y (2013). Isolation and identification of antioxidant peptides from Jinhua ham. Journal of Agricultural and Food Chemistry 61(6): 1265-1271. https://doi.org/10.1021/jf3044764

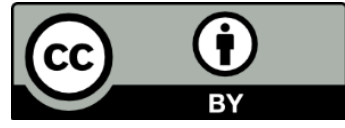

(C) 2022 by the author(s). Published by Ankara University, Faculty of Agriculture, Ankara, Turkey. This is an Open Access article distributed under the terms and conditions of the Creative Commons Attribution (CC BY) license (http://creativecommons.org/licenses/by/4.0/), which permits unrestricted use, distribution, and reproduction in any medium, provided the original work is properly cited. 